\title{
MONITORING SISTEM BERBASIS WEB KEAMANAN TRANSAKSI PENGIRIMAN UANG PADA PENYELENGGARA TRANSFER DANA DENGAN MENGGUNAKAN PERATURAN BANK INDONESIA ANTI PENCUCIAN UANG \& PENCEGAHAN PENDANAAN TERORISME
}

\author{
Rahmat Rian Hidayat ${ }^{1,}$ Dwiki Jatikusumo ${ }^{2}$ \\ Jurusan Teknik Informatika, Fakultas Ilmu Komputer, Universitas Mercu Buana ${ }^{1,2}$ \\ Jl. Raya Meruya Selatan, Kembangan, Jakarta, 11650 \\ Email: $\underline{\text { rahmat.rian@mercubuana.ac.id }}{ }^{1}$,dwiki.jatikusumo@ mercubuana.ac.id ${ }^{2}$
}

\begin{abstract}
PT BETANET as Non-Bank Fund Transfer Provider has an obligation to comply the provisions of 19/10 / PBI / 2017 concerning about Anti-Money Laundering and Combating the Financing of Terrorism and the Proliferation of Weapons of Mass Destruction. (AML/CFTWMD) for Non-Bank Payment System Service Providers and Non-Bank Foreign Currency Exchange Business Operators. Having Remittance partners abroad and Domestic transactions with an average of 50 thousand transactions per month, BETANET must have a special AML \& CFT unit to ensure that fund transfer activities are complies with the PBI about AML \& CFT. The duties of the AML \& CFT Unit are routinely ensure that funds transfer transactions which are deemed suspicious or not. The parameter of suspicious transaction has been set out in the policy. However, the current conditions of BETANET, it does not have a monitoring system which is integrated with the Host Remittance System. It means that the AML \& CFT activities are still carried out manually every day, so that it will create several risks such as Operational risk, Reputation risk, Legal risk. Judging from these conditions and problems, this study will propose to build a security system for web-based fund transfer transactions. Based on the results of system monitoring, there is no need to do manual checking for suspicious transactions. The AML \& CFT Officer will get an Alert or Notification to the Email automatically every day. So they can run the next process such as Enhanced Due Diligenced (EDD) to partners if any suspicious transaction found. It helps Financial Transaction Reporting and Analysis Center (FTRAC) for transactions of Suspected Terrorist Lists and Terrorist Organizations (STLTO), as well as the List of Anti-Money Laundering and Combating the Financing of Terrorism and the Proliferation of Weapons of Mass Destruction. $(A M L / C F T W M D)$
\end{abstract}

Keywords: Funds Transfer, AML \& PTF, Website, Risk, Security, PBI, Transactions 


\begin{abstract}
ABSTRAK
PT BETANET sebagai Penyelenggara Transfer Dana (PTD) Non Bank memiliki kewajiban untuk mematuhi ketentuan 19/10/PBI/2017 tentang Anti Pencucian Uang \& Pencegahan Pendanaan Terorisme (APU\&PPT) bagi Penyelenggara Jasa Sistem Pembayaran Selain Bank dan Penyelenggara Kegiatan Usaha Penukaran Uang Asing Bukan Bank. Dengan memiliki mitra Remittance di luar negeri dan Domestik transaksi yang melalui BETANET rata-rata 50 Ribu transaksi per bulan. Dengan begitu pada BETANET harus memiliki unit khusus APU\&PPT untuk memastikan kegiatan transfer dana patuh terhadap PBI APU\&PPT, adapun tugas dari Unit $A P U \& P P T$ secara rutin memastikan transaksi pengiriman dana yang dianggap mencurigakan sesuai parameter yang telah diatur dalam kebijakan. Namun kondisi saat ini pada BETANET belum memiliki monitoring system yang terintegrasi dengan Host Sistem Remittance dalam artian kegiatan APU\&PPT tersebut masih dilakukan manual setiap harinya. Sehingga akan menimbulkan beberapa risiko seperti risiko Operasional, risiko Reputasi, risiko Hukum. Dilihat dari kondisi dan permasalahan tersebut maka penelitian ini akan mengusulkan untuk membangun sebuah sistem keamanan transaksi transfer dana berbasis web. Berdasarkan hasil pembuatan monitoring sistem tidak perlu dilakukan manual lagi dalam pengecekan transaksi yang mencurigakan, kemudian setiap hari secara sistem Petugas APU\&PPT akan mendapatkan Alertatau Notifikasi ke Email dapat menjalankan proses selanjutnya seperti Enhanced Due Diligenced (EDD) kepada mitra apabila ditemukan transaksi mencurigakan dan dapat memudahkan untuk melaporkan ke Pusat Pelaporan dan Analisis Transaksi Keuangan (PPATK) untuk transaksi dalam kategori Daftar Terduga Teroris dan Organisasi Teroris (DTTOT), serta Daftar Proliferasi Pemusnahan Senjata Massal.
\end{abstract}

Kata kunci: Transfer Dana, APU\& PPT, Website, Risiko, Security, PBI, Transaksi 


\section{JURNAL PETIR}

Vol. 12, No. 1, Maret 2019, P-ISSN 1978-9262, E-ISSN 2655-5018

\section{PENDAHULUAN}

Money laundering (pencucian uang) didefinisikan sebagai rangkaian kegiatan yang merupakan proses yang dilakukan oleh seseorang atau organisasi terhadap uang haram, yaitu uang yang berasal dari kejahatan, dengan maksud untuk menyembunyikan atau menyamarkan asal-usul uang tersebut dari pemerintah atau otoritas yang berwenang melakukan tindakan terhadap tindak pidana dengan cara terutama memasukkan uang tersebut ke dalam sistem keuangan sehingga uang tersebut selanjutnya dapat dikeluarkan dari system keuangan itu sebagai uang yang halal. ${ }^{1}$ Convention against Transnasional Organized Crime mendefinisikan money laundering sebagai salah satu bentuk Transnasional Organized Crime, di samping korupsi, penyelundupan orang asing, dan perdagangan wanita dan anak-anak. Meskipun Indonesia telah memiliki regulasi terkait tindak pidana pencucian uang namun belum diimplementasikan dengan baik, masih marak terjadi pencucian uang oleh perorangan ataupun korporasi yang berasal dari hasil korupsi dan digunakan untuk pendanaan terorisme dan perdaganagn senjata illegal. Secara internal masih sulit untuk melakukan pengecekan terhadap transaksi-transaksi mencurigakan yang terindikasi money laundering.

Secara internasional, Indonesia menjadi anggota aktif The Egmont Group dan Asia/Pacific Group on Money Laundering (APG) yang mengadopsi rekomendasi dan standar internasional secara lebih komprehensif yang dikeluarkan oleh Financial Action Task Force (FATF), organisasi internasional yang memerangi tindak pidana pencucian uang. Saat ini status Indonesia sebagai negara observer dan masih dalam proses memperoleh keanggotaan FATF. Berdasarkan on-site visit mutual evaluation review (MER) yang dilakukan pihak APG, Indonesia telah memenuhi persyaratan menjadi anggota FATF, termasuk menyelesaikan proses MER pada November 2017 dan menyempurnakan regulasi.

Bank Indonesia sebagai salah satu pihak yang bertindak sebagai pengawas industri turut berpartisipasi dengan mengeluarkan PBI No 19/10 tahun 2017 tentang Anti Pencucian Uang dan Pencegahan Pendanaan Terorisme (APU PPT). Dalam hal ini PT BETANET sebagai Penyelenggara Transfer Dana yang mendapat izin dari Bank Indonesia harus mematuhi dan menjalankan ketententuan dari PBI No 19/10 tahun 2017 tersebut. Anti Pencucian Uang dan Pencegahan Pendanaan Terorisme yang selanjutnya disebut APU dan PPT adalah upaya pencegahan dan pemberantasan tindak pidana Pencucian Uang dan Pendanaan Terorisme. Pencucian Uang adalah pencucian uang sebagaimana dimaksud dalam Undang-Undang yang mengatur mengenai pencegahan dan pemberantasan tindak pidana pencucian uang.

Pendanaan Terorisme adalah pendanaan terorisme sebagaimana dimaksud dalam UndangUndang yang mengatur mengenai pencegahan dan pemberantasan tindak pidana pendanaan terorisme.

Transfer Dana adalah transfer dana sebagaimana dimaksud dalam Undang-Undang yang mengatur mengenai transfer dana. [3].

PT BETANET memiliki mitra dari luar negeri dan dalam negeri, rata-rata transaksi per bulan berdasarkan volume mencapai 50 Ribu transaksi. Dengan demikian menjadi pekerjaan dari Petugas APU\&PPT untuk melakukan monitoring transaksi yang mencurigakan yang masuk kategori sesuai parameter yang telah ditentukan pada kebijakan perusahaan. Monitoring transaksi ini dilakukan manual setiap hari dengan menarik hasil laporan atau jurnal transaksi dengan format Excel.

Penelitian ini, akan membangun sebuah sistem keamanan transaksi transfer dana yang berbasis web, sehingga monitoring sistem tidak perlu dilakukan manual lagi dalam pengecekan transaksi yang mencurigakan, kemudian setiap hari secara sistem Petugas APU\&PPT akan mendapatkan Alert atau Notifikasi ke Email dapat menjalankan proses selanjutnya seperti Enhanced Due Diligenced (EDD) kepada mitra apabila ditemukan transaksi mencurigakan dan dapat memudahkan untuk melaporkan ke Pusat Pelaporan dan Analisis Transaksi Keuangan (PPATK) untuk transaksi dalam kategori Daftar Terduga Teroris dan Organisasi Teroris (DTTOT), serta Daftar Proliferasi Pemusnahan Senjata Massal. 


\section{METODE/PERANCANGAN PENELITIAN}

Metode penelitian disusun secara terstruktur degan baik. Adapun langkah-langkah yang dilakukan dari penelitian ini seperti digambarkan pada kerangka pikir penelitian yang bisa dilihat pada gambar 1.1.

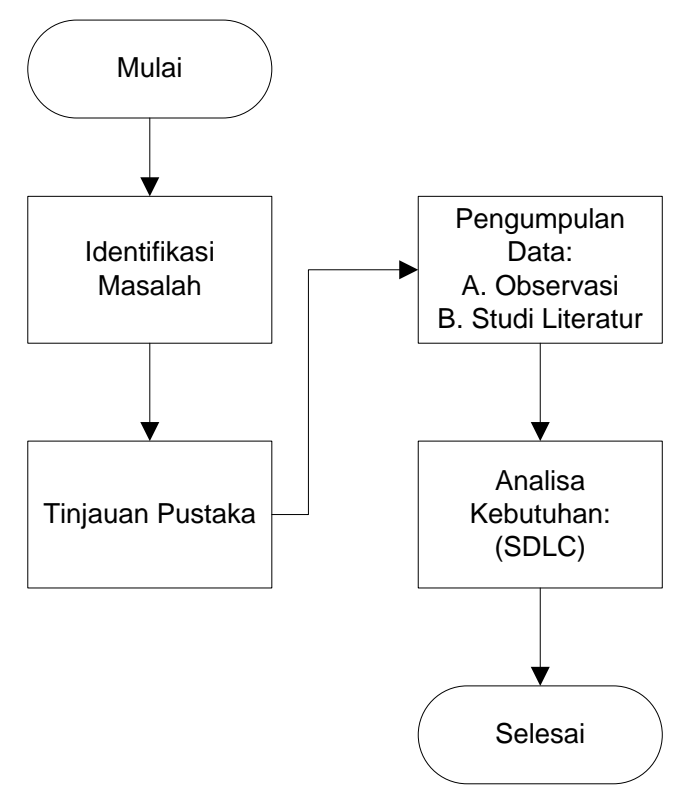

Gambar 1.1 Kerangka Pikir

Penjelasan pada tahapan kerangka pikir tersebut adalah sebagai berikut :

\subsection{Identifikasi Masalah}

Tahap ini merumuskan masalah yang dilakukan terlebih dahulu melihat kondisi aktual di lapangan. Selanjutnya menentukan tujuan dari sasaran yang ingin diwujudkan dalam penyelesaian permasalahan yang diteliti.

\subsection{Tinjauan Pustaka}

Tahap ini mempelajari dan mencari literatur pendukung yang berhubungan dengan teori, tools serta metode yang digunakan.

\subsection{Pengumpulan Data}

Tahap ini mengumpulkan data dengan dua cara yaitu observasi dan studi literatur.

a. Observasi

Observasi dilakukan dengan mengumpulkan data dan informasi yang dibutuhkan dalam perancangan, pengembangan sistem serta proses kegiatan dari sistem aplikasi yang diterapkan.

b. Studi Literatur

Studi literatur dilakukan dengan mengumpulkan data dari riset terdahulu, pembelajaran dari berbagai macam literatur dan dokumen seperti buku, jurnal dan teori yang mendukung, peralatan akan digunakan dan data penunjang lainnya.

\subsection{Analisa Kebutuhan}

Analisis kebutuhan sistem aplikasi dilakukan untuk mengetahui kebutuhan pengguna terhadap aplikasi yang dikembangkan. Hal ini perlu dilakukan agar aplikasi yang dikembangkan sesuai dengan kebutuhan pengguna. 
Adapun tahapan pengembangan yang digunakan dalam penelitian ini terdiri dari Metode pengembangan sistem Software Development Life Cycle (SDLC) yang meliputi tahapan dapat di lihar pada gambar 2. 1 sebagai berikut:

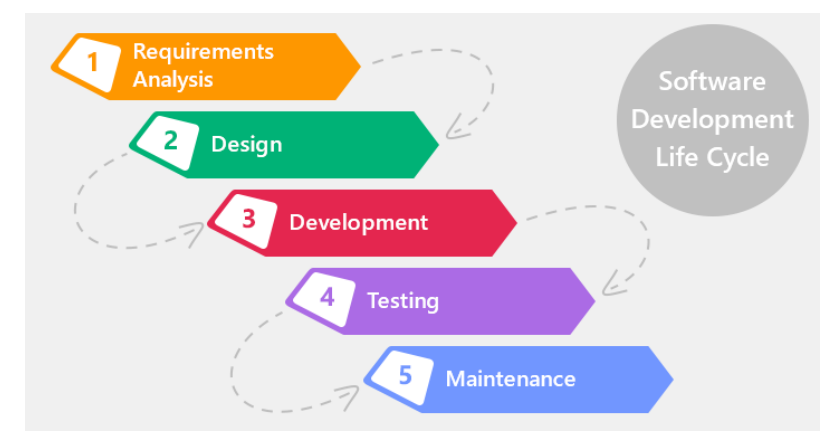

Gambar 2.1 Model SDLC

(xbsoftware.com, 2018)

\section{1) Requirements Analysis}

Tahap ini menjelaskan dari hasil observasi kepada user dalam bentuk dokumen requirement yang biasanya disebut dengan URS (User Requirement System).

\section{2) Design}

Tahap ini membuat perancangan aplikasi meliputi, merancangan tampilan user, merancang basis data untuk aplikasi tersebut agar manajemen file yang ada lebih teratur.

Pada bagian ini juga membuat tahapan-tahapan proses dari model arsitektur system yang dibuat seperti pada gambar 2.2 berikut ini:

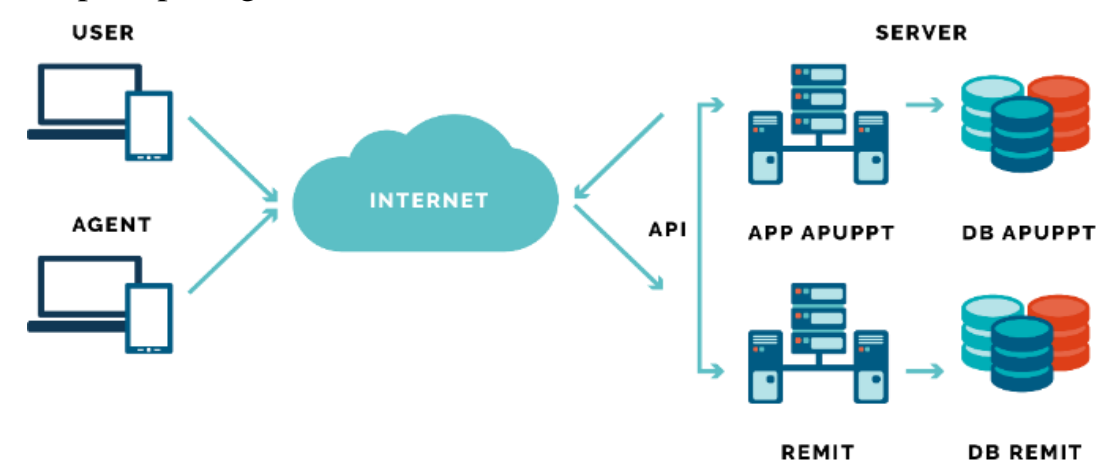

Gambar 2.2 Model Arsitektur

Pada gambar tersebut terdapat server untuk aplikasi dan database masing-masing untuk aplikasi monitoring APU PPT dan Aplikasi Remittance (Aplikasi Transfer dana). Monitoring sistem ini bekerja dengan cara membuat API antara sistem APU PPT dan sistem Remittance. Transaksi akan digenerate di sistem APU\& PPT pada saat Cutt Off. Transaksi yang di generate adalah transaksi Remittance dan akan dapat dilihat di web monitoring oleh user setelah hari berikutnya.

\section{3) Development}

Tahap ini menjelaskan proses development yang dapat dimengerti oleh mesin, dalam hal ini adalah komputer untuk pemrograman melalui proses coding.

\section{4) Testing}


Tahap ini melakukan uji coba pada system aplikasi yang telah dibuat, sehingga memastikan semua fungsi-fungsi aplikasi benar sesuai dengan kebutuhan yang didefinisikan sebelumnya, dalam artian tidak ada lagi yang error.

\section{5) Maintenance}

Tahap ini proses monitoring system yang telah di rilis di production sehingga apabila terdapat system bug perlu diperbaiki dan dilakukan pengembangan system tersebut serta dilakukan evaluasi hasil manfaat cara dengan membandingkan hasil yang didapatkan dengan kebutuhan pengguna.

\section{HASIL DAN PEMBAHASAN}

\section{a. Hasil Flow System APU\&PPT}

Berikut ini penjelasan mengenai flow pada aplikasi monitoring system APU\& PPT yang telah dibuat:

1. Tersedia server APU\&PPT yang menggunakan JAVA dan server Remittance menggunakan PHP Zend Framework

2. Sebagai penghubung antara kedua server tersebut membuat API

3. Data transaksi akan digenerate di Server Remitt pada saat cutt off setiap hari

4. Hasil generate transaksi akan disimpan di DB APU\&PPT

5. User APU\&PPT akan mengakses untuk monitoring transaksi pada website APU\&PPT setiap hari.
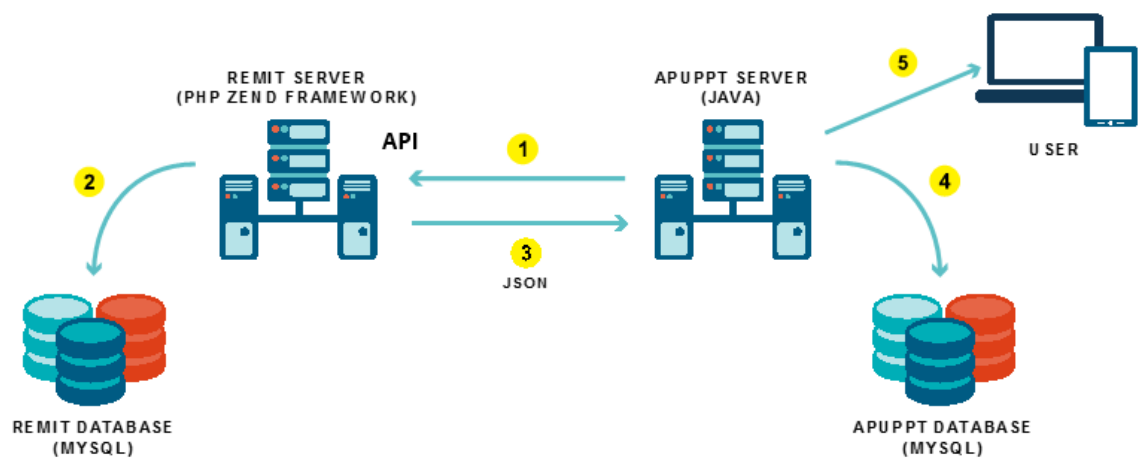

Gambar 3.1 Skenario System

\section{b. Hasil Tampilan Website}

Aplikasi yang dihasilkan adalah sebuah Web sistem, web ini dirancang untuk membantu petugas APU\&PPT yang selama ini belum ada sistem monitoring, sehingga dalam pengecekan transaksi mencurigakan dapat dengan mudah ditemukan.

\section{a. Halaman Login}

Berikut ini adalah halaman login dari website monitoring transaksi. Pada halaman ini admin menginput username dan password untuk bisa mengakses website monitoring APU\&PPT. 


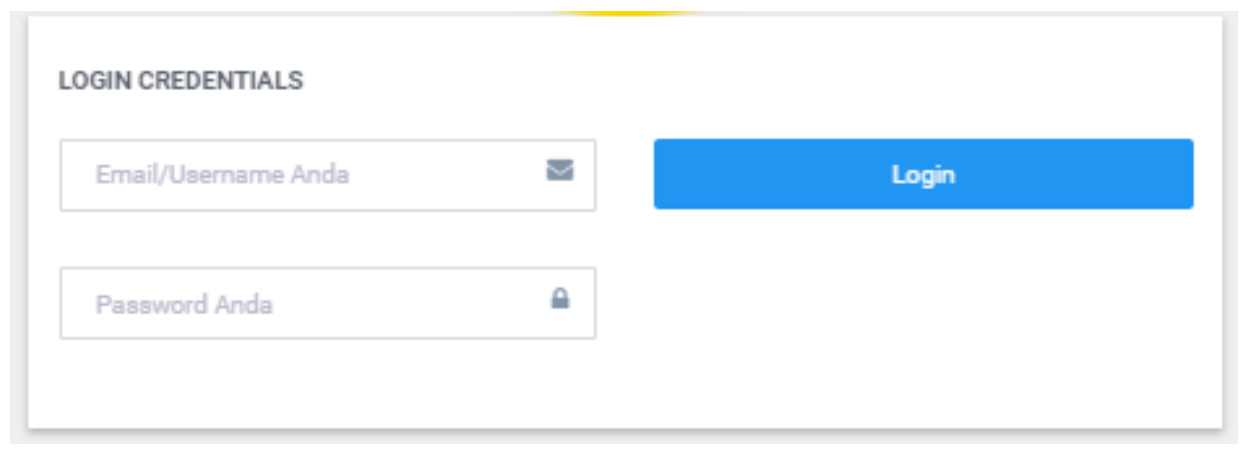

Gambar 3.2 Halaman Login

\section{b. Halaman Dashboard}

Berikut ini adalah halaman Dashboard dari website monitoring transaksi. Ini adalah halaman tampilan awal pada website monitoring APU\&PPT.

Pada detail dashboard terdapat 4 kotak :

1. LTKM by value ( $>100$ Juta) (kotak warna merah) yaitu resume ketika ada Laporan Transaksi Keuangan Mencurigakan berdasarkan jumlah nilai dalam durasi 1 hari berapa kali transaksi dengan jumlah total lebih dari 100 juta

2. View LTKM by sender yaitu resume dalam 1 hari ditemukan ada lebih dari transaksi 11x pengiriman maka akan muncul notif ke dalam kolom tersebut.

3. View LTKM by DTTOT dan Profelirasi yaitu resume terdetect ada aktifitas transaksi dengan nama yang termasuk ke dalam Daftar Terduga Teroris dan Organisasi Teroris dan Daftar Pendanaan Proliferasi Senjata Pemusnah Massal

4. View LTKM by PEP yaitu politically exposed persons yang terindikasi dalam tindak pidana terdetect maka akan muncul notif ke kolom tersebut.

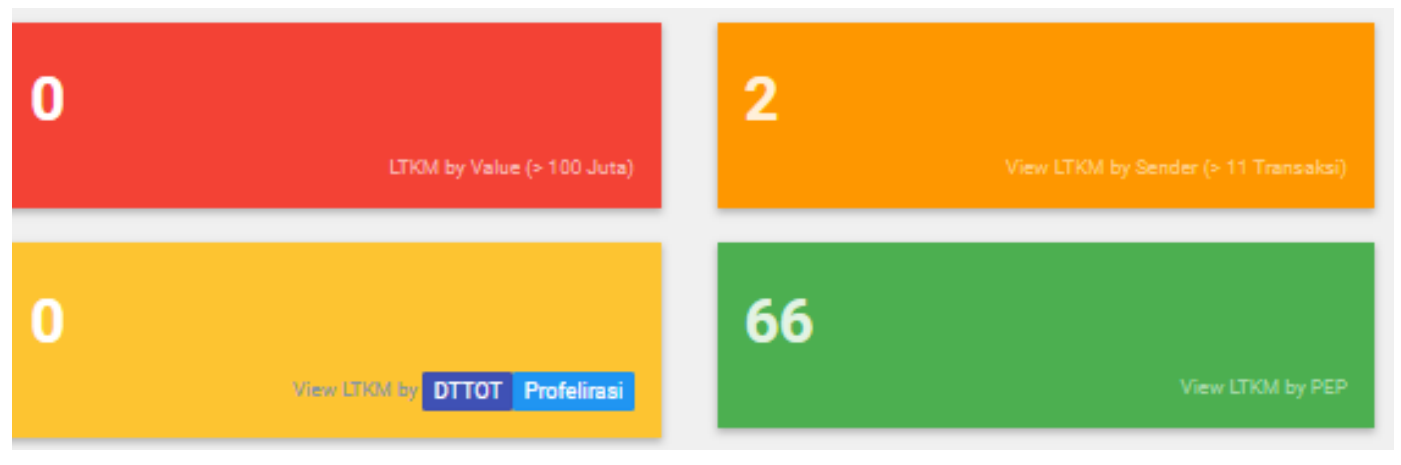

Gambar 3.3 Dashboar pada Monitoring System

\section{c. Halaman Laporan LTKM by Value}

Berikut ini adalah halaman Laporan LTKM by Value dari website monitoring transaksi. Ini adalah halaman Laporan LTKM by Value pada website monitoring APU\&PPT. Halaman ini menampilkan detail transaksi yang mencurigakan berdasarkan jumlah nilai dalam durasi 1 hari berapa kali transaksi dengan jumlah total lebih dari 100 juta. 

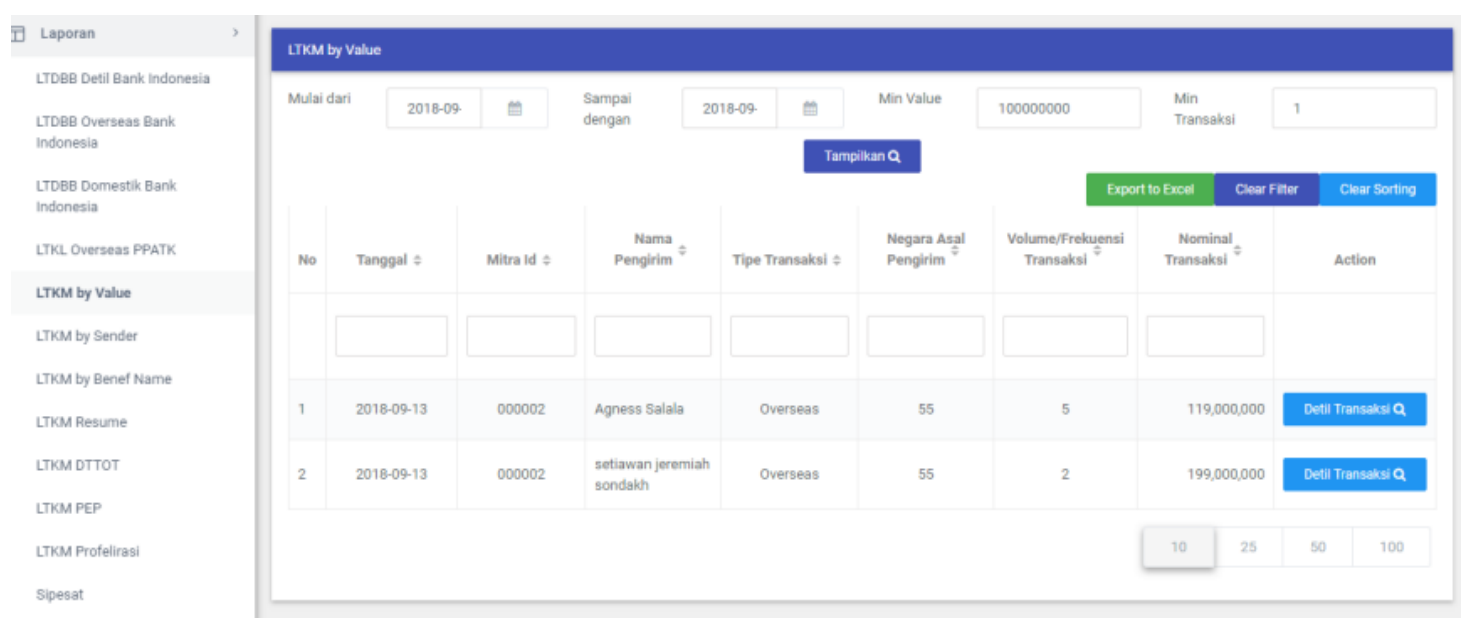

Gambar 3.4 Laporan LTKM by Value

\section{d. Halaman Laporan LTKM by Sender}

Berikut ini adalah halaman Laporan LTKM by Sender dari website monitoring transaksi. Ini adalah halaman Laporan LTKM by Sender pada website monitoring APU\&PPT. Halaman ini menampilkan detail transaksi yang mencurigakan dalam 1 hari ditemukan ada lebih dari transaksi $11 x$ pengiriman maka akan muncul notif ke dalam kolom tersebut.

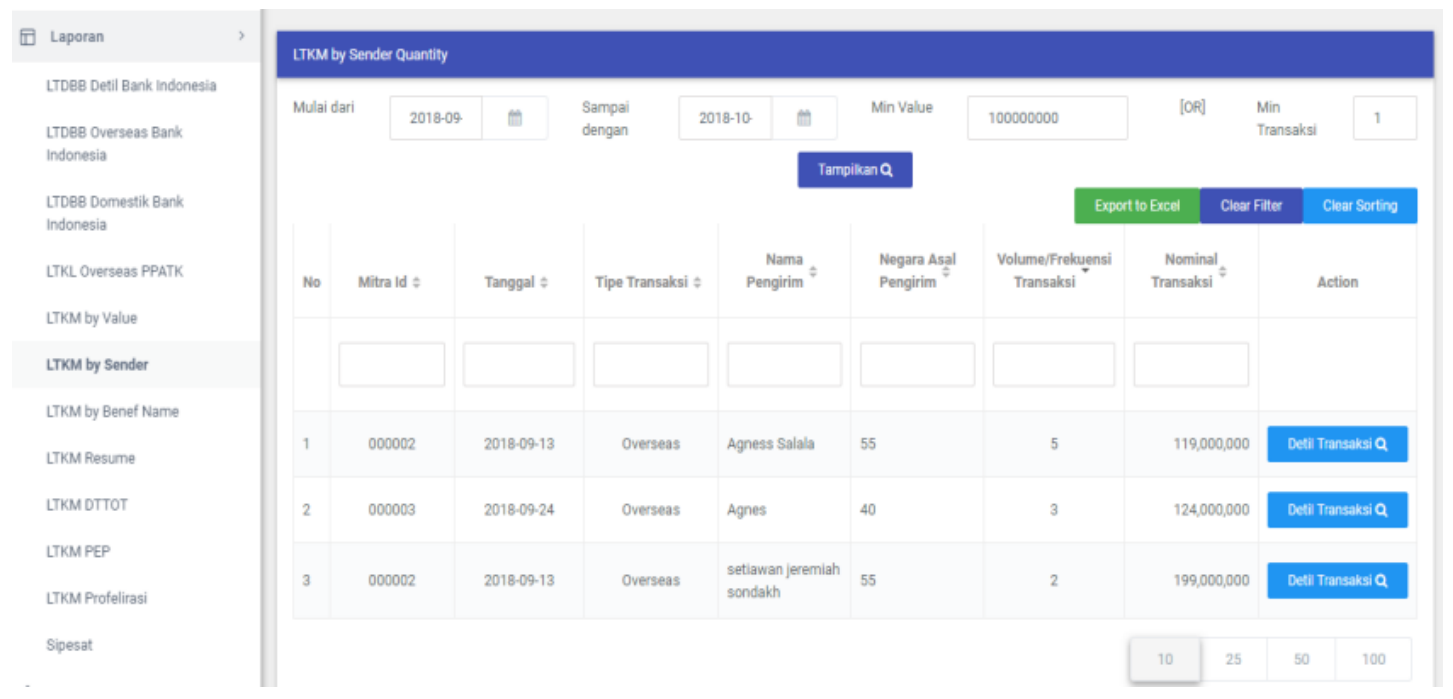

Gambar 3.5 Laporan LTKM by Sender

\section{e. LTKM by DTTOT dan Profelirasi}

Berikut ini adalah halaman LTKM by DTTOT dari website monitoring transaksi. Ini adalah halaman LTKM by DTTOT pada website monitoring APU\&PPT. Halaman ini menampilkan detail transaksi yang mencurigakan adanya ada aktifitas transaksi dengan nama yang termasuk ke dalam Daftar Terduga Teroris dan Organisasi Teroris dan Daftar Pendanaan Proliferasi Senjata Pemusnah Massal 

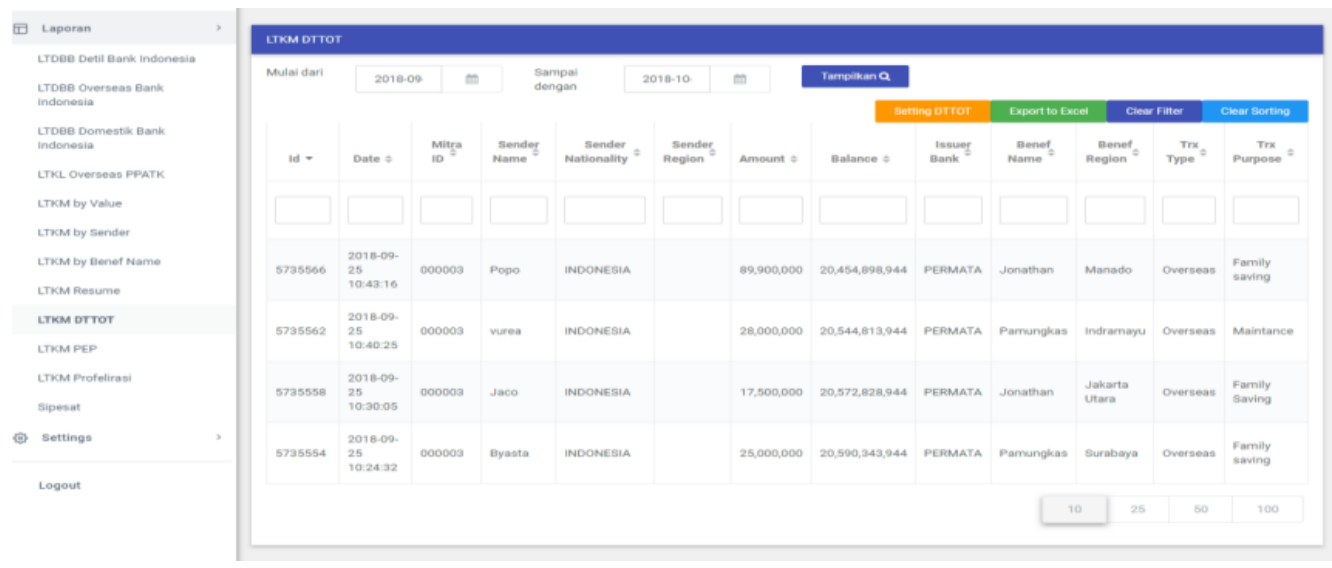

Gambar 3.6 Laporan LTKM by DTTOT

\section{f. Halaman Laporan LTKM PEP}

Berikut ini adalah halaman LTKM PEP dari website monitoring transaksi. Ini adalah halaman LTKM PEP pada website monitoring APU\&PPT. Halaman ini menampilkan detail transaksi yang mana terdapat nama PEP (politically exposed persons).
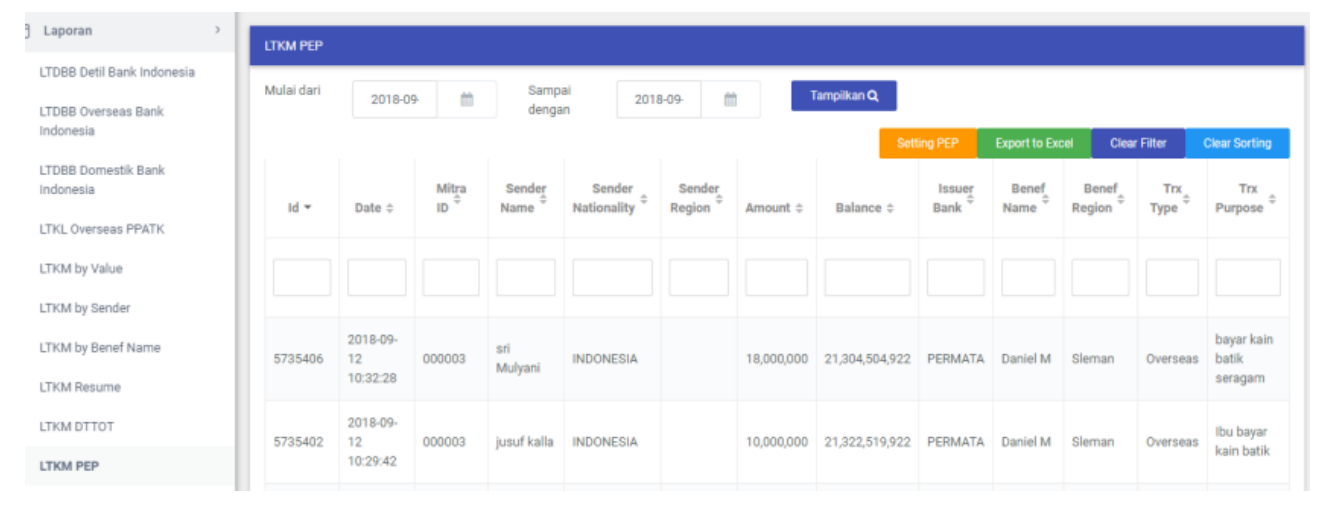

Gambar 3.7 Laporan LTKM by PEP

\section{g. Halaman Laporan LTKM Profelirasi}

Berikut ini adalah halaman LTKM Profelirasi dari website monitoring transaksi. Ini adalah halaman LTKM Profelirasi pada website monitoring APU\&PPT. Halaman ini menampilkan detail transaksi yang mana terdapat nama yang terdaftar dari daftar Profelirasi Pemusanahan Senjata Massal.
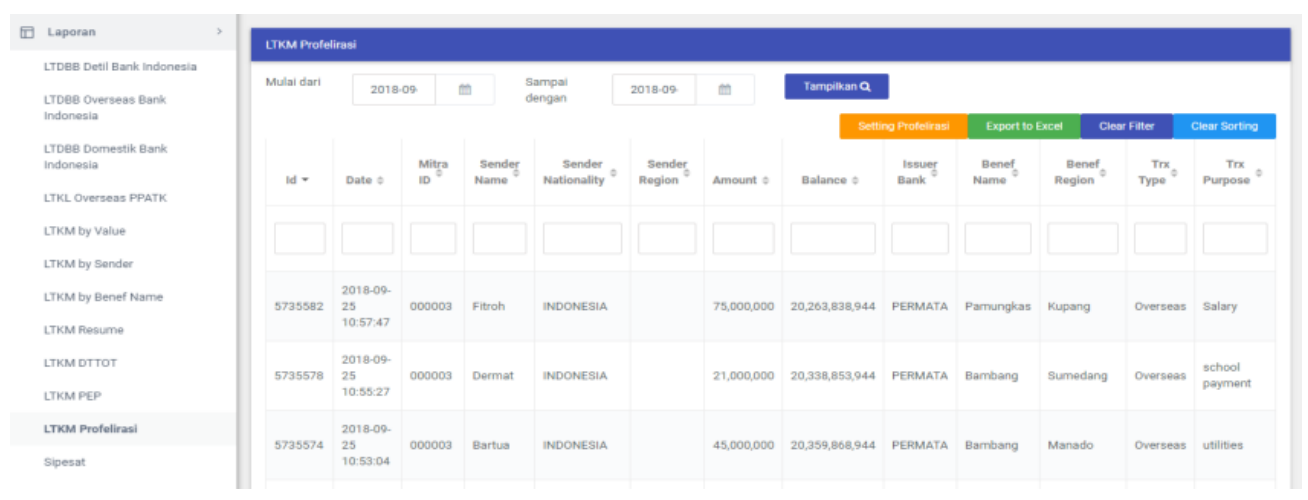

Gambar 3.8 Laporan LTKM by Profelirasi 


\section{h. Halaman Laporan LTKL Overseas PPATK}

Berikut ini adalah halaman LTKL Overseas PPATK dari website monitoring transaksi. Ini adalah halaman LTKL Overseas PPATK pada website monitoring APU\&PPT. Halaman ini menampilkan detail transaksi yang tergolong transaksi luar negeri yang disesuaikan dengan format Web pelaporan PPATK sehingga memudahkan admin/petugas untuk upload di website PPATK.

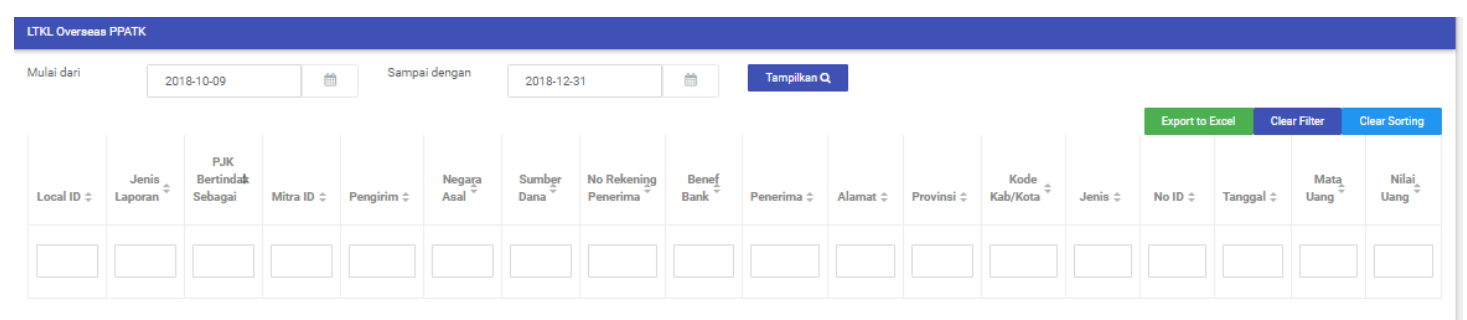

Gambar 3.9 Laporan LTKL Overseas PPATK

\section{i. Halaman Laporan LTKL Overseas PPATK}

Berikut ini adalah tampilan dari Notifikasi Email diatas terdapat hasil tujuh kategori yang masuk dalam parameter sesuai dengan kebijakan perusahaan yaitu:

1. Nilai transaksi lebih dari atau sama dengan 100 Juta: Nilai transaksi yang dilakukan oleh pengirim/penerima dalam satu hari mencapai 100 juta atau lebih.

2. Frekuensi transaksi pengiriman lebih dari atau sama dengan 11: Pengirim dan penerima melakukan transaksi sebanyak 11 kali atau lebih dalam satu hari menggunakan Account Bank yang sama. Hal ini berlaku juga apabila mengirimkan atau menerima dari/ke rekening sendiri.

3. Politically Exposed Person (PEP) : Keterangan ini menjelaskan nama pengirim atau penerima dana yang termasuk dalam kategori PEP.

4. Daftar Terduga Teroris dan Organisasi Teroris (DTTOT) : Pada keterangan ini menginformasikan DTTOT, sumber DTTOT ini dari PPATK dan Bank Indonesia.

5. Domestic: Menjelaskan jumlah transaksi harian yang melalu sistem BETANET dari mitra dalam negeri.

6. Overseas: Menjelaskan jumlah transaksi harian yang melalu sistem BETANET dari mitra Luar negeri.

$\begin{array}{llc}\text { No Data } & \text { Jumlah Data } \\ 1 & \text { Nilai Transaksi lebih dari atau sama dengan 100.0Jt } & 1 \\ 2 & \text { Frekuensi Transaksi Pengiriman lebih dari atau sama dengan } 11 & 2 \\ 3 & \text { PEP } & 49 \\ 4 & \text { DTTOT } & 0 \\ 5 & \text { Profelirasi } & 0 \\ 6 & \text { Domestic } & 365 \\ 7 & \text { Overseas } & 1485\end{array}$

Gambar 3.10 Laporan Hasil Analisa System By Email

\section{c. Hasil Pengujian User}

User Acceptance Test (UAT) atau Uji Penerimaan Pengguna adalah suatu proses pengujian oleh pengguna yang dimaksudkan untuk menghasilkan dokumen yang dijadikan bukti bahwa software yang telah dikembangkan telah dapat diterima oleh pengguna, apabila hasil pengujian sudah bisa dianggap memenuhi kebutuhan dari pengguna. Proses UAT didasarkan pada dokumen requirement yang disepakati bersama. Dokumen requirement adalah dokumen yang berisi lingkup pekerjaan software yang harus dikembangkan, dengan 


\section{JURNAL PETIR}

Vol. 12, No. 1, Maret 2019, P-ISSN 1978-9262, E-ISSN 2655-5018

demikian maka dokumen ini semestinya menjadi acuan untuk pengujian. Dalam hal ini dilakukan ke 12 rekan kantor yang menguji web monitoring ini, yang terdiri dari IT, Compliance, Operation. Pada penelitian ini, dokumen UAT dapat dijelaskan pada tabel berikut, menggunakan google form:

Tabel 3.1 Hasil Pengujian Black Box

\begin{tabular}{|l|l|l|l|}
\hline No & \multicolumn{1}{|c|}{ Pertanyaan } & \multicolumn{1}{|c|}{ Tujuan } & Keterangan \\
\hline 1 & $\begin{array}{l}\text { Apakah Informasi Pengguna } \\
\text { Website sudah lengkap? }\end{array}$ & $\begin{array}{l}\text { Mengetahui data informasi dari } \\
\text { transaksi yang termasuk kategori } \\
\text { LTKM, DTTOT \& Profelirasi }\end{array}$ & Terpenuhi \\
\hline 2 & $\begin{array}{l}\text { Apakah Ukuran Tulisan di } \\
\text { Aplikasi dapat terlihat dengan } \\
\text { jelas? }\end{array}$ & $\begin{array}{l}\text { Melihat Ukuran tulisan secara jelas } \\
\text { (User Friendly) }\end{array}$ & Terpenuhi \\
\hline 3 & $\begin{array}{l}\text { Apakah Web Monitoring dapat } \\
\text { diakses mudah dari } \\
\text { Smartphone/PC? }\end{array}$ & $\begin{array}{l}\text { Dapat di akses menggunakan } \\
\text { Smartphone selain PC. }\end{array}$ & $\begin{array}{l}\text { Cukup } \\
\text { Terpenuhi }\end{array}$ \\
\hline 4 & $\begin{array}{l}\text { Apakah dengan Monitoring } \\
\text { Sistem ini mempermudah } \\
\text { Petugas APU PPT? }\end{array}$ & $\begin{array}{l}\text { Dengan adanya Monitoring sistem } \\
\text { memberikan kemudahan bagi } \\
\text { petugas APU\&PPT }\end{array}$ & Terpenuhi \\
\hline 5 & $\begin{array}{l}\text { Apakah tampilan menu awal } \\
\text { sudah user friendly? }\end{array}$ & $\begin{array}{l}\text { Tampilan menu awal (Dashboard) } \\
\text { sudah user friendly. }\end{array}$ & $\begin{array}{l}\text { Sangat } \\
\text { Terpenuhi }\end{array}$ \\
\hline
\end{tabular}

\section{KESIMPULAN DAN SARAN}

Kesimpulan dari penelitian yang telah dilakukan untuk menjawab rumusan permasalahan adalah memberikan informasi bagaimana membuat monitoring sistem berbasis web untuk transaksi mencurigakan berdasarkan value, frekuensi, pengirim dan penerima dana. Dari Monitoring web sistem tersebut monitoring sistem tidak perlu dilakukan manual lagi dalam pengecekan transaksi yang mencurigakan, kemudian setiap hari secara sistem Petugas APU\&PPT akan mendapatkan Alert atau Notifikasi ke Email dapat menjalankan proses selanjutnya seperti Enhanced Due Diligenced (EDD) kepada mitra apabila ditemukan transaksi mencurigakan dan dapat memudahkan untuk melaporkan ke Pusat Pelaporan dan Analisis Transaksi Keuangan (PPATK) untuk transaksi dalam kategori Daftar Terduga Teroris dan Organisasi Teroris (DTTOT), serta Daftar Proliferasi Pemusnahan Senjata Massal.

Saran monitoring website ini dapat dilakukan realtime ketika transfer dana yang dianggap mencurigakan dapat memunculkan Notifikasi langsung atau memberikan aleart karena pada saat ini masih menganalisa transaksi $\mathrm{H}-1$.

\section{UCAPAN TERIMAKASIH}

Dalam penyusunan riset ini tidak terlepas dukungan dari berbagai pihak. Secara khusus mengucapkan terima kasih yang sebesar-besarnya kepada semua pihak tang telah membantu. Peneliti banyak menerima bimbingan, petunjuk dan bantuan serta dorongan dari berbagai pihak yang bersifat moral dan material. Pada kesempatan ini penulis menyapaikan rasa terima kasih yang sebesar-besarnya kepada:

1. Allah SWT dengan segala rahmat serta karunia-Nya yang memberikan kekuatan bagi peneliti dalam menyelesaikan riset ini.

2. Kepada Ibu Desi Ramayanti,S.Kom, MT selaku Kaprodi Teknik Informatika Universitas Mercu Buana, Jakarta

3. Kepada Ibu Dr. Ida Nurhaida, MT selaku ketua kelompok riset Bidang Ilmu informatika Universitas Mercu Buana, Jakarta

91 | Jurnal PETIR 
4. Kepada Ibu Dr. Devi Fitrianah, S.Kom., MTI selaku Kepala Pusat Penelitian Universitas Mercu Buana, Jakarta.

5. Segenap dosen dan seluruh staf akademik yang selalu membantu dalam memberikan fasilitas, ilmu.dll.

6. Kepada pihak PT Betanet yang memberikan kesempatan bagi peneliti untuk dapat melangsungkan penelitian dan memperoleh data.

\section{DAFTAR PUSTAKA}

[1] Sutan Remy Sjahdaeni, Pencucian Uang: Pengertian, Sejarah, Faktor-faktor Penyebab dan Dampaknya bagi Masyarakat, Jurnal Hukum Bisnis, Vol.22 No.3, Tahun 2003.

[2] www.bi.go.id, 2018 PBI/ 19/10/PBI/2017 tentang Anti Pencucian Uang \& Pencegahan Pendanaan Terorisme (APU\&PPT) bagi Penyelenggara Jasa Sistem Pembayaran Selain Bank dan Penyelenggara Kegiatan Usaha Penukaran Uang Asing Bukan Bank. (Diakses pada tanggal 4 Oktober 2018 https://www.bi.go.id/ PBI/ 19/10/PBI/2017 tentang Anti Pencucian Uang \& Pencegahan Pendanaan Terorisme (APU\&PPT) bagi Penyelenggara Jasa Sistem Pembayaran Selain Bank dan Penyelenggara Kegiatan Usaha Penukaran Uang Asing Bukan Bank.

[3] www.fatf-gafi.org, 2018, Financial Action Task Force (Diakses pada tanggal 5 Oktober 2018 http://www.fatf-gafi.org/)

[4] scdc.binus.ac.id, 2016, pengertian sistem informasi (diakses pada tanggal 18 Oktober 2018, http://scdc.binus.ac.id/himsisfo/2016/07/pengertian-sistem-informasi/)

[5] xbsoftware.com, 2018, Software Development Life Cyle, (Diakses pada tanggal 17 Oktober 2018, https://xbsoftware.com/web-app-dev/custom-web-application-development/) www.codegravity.com, 2018 The basic architecture of Java EE microservices

[6] (diakses (Pada tanggal 29 Juni 2018, http://www.codegravity.com/blog/emerging-trend-ofjava-ee-microservices) 